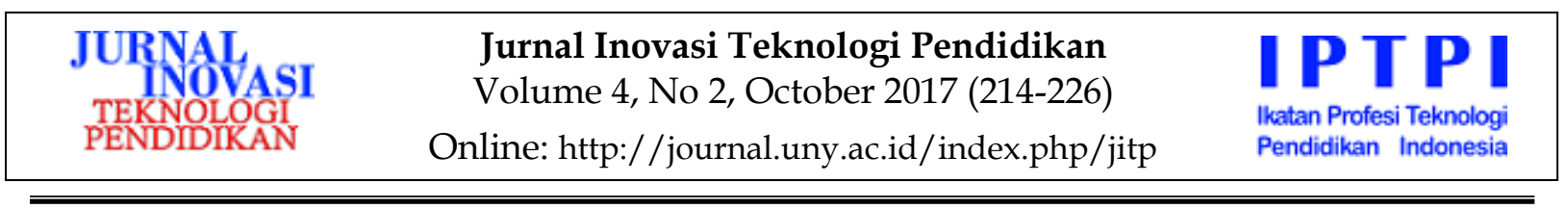

\title{
EVALUASI BAHAN AJAR BAHASA PRANCIS LE MAG SEBAGAI BAHAN PEMBELAJARAN MANDIRI SISWA SEKOLAH MENENGAH ATAS
}

\author{
Kartika Permata Sari \\ Prodi Teknologi Pembelajaran PPs UNY \\ saripermata.kartika@gmail.com
}

\begin{abstract}
Abstrak
Tujuan penelitian ini adalah mengetahui kualitas bahan ajar Bahasa Prancis Le Mag yang digunakan oleh siswa sebagai sumber belajar dalam proses pembelajaran. Kriteria yang digunakan untuk mengevaluasi bahan ajar ini adalah kriteria dari aspek desain instruksional, aspek desain pesan dan aspek karakteristik siswa.Penelitian ini merupakan penelitian evaluasi dengan pendekatan kuantitatif. Model evaluasi yang digunakan adalah model evaluasi formatif oleh Dick and Carey yang dilakukan dengan dua tahap, yaitu evaluasi one to one by expert dan evaluasi one to one by student. Instrumen yang digunakan adalah lembar penilaian bahan ajar. Hasil penelitian menunjukkan bahwa bahan ajar Le Mag sebagai bahan ajar bahasa Prancis memiliki kualitas baik untuk digunakan sebagai bahan ajar mandiri siswa SMA dalam proses pembelajaran. Kualitas tersebut berdasarkan penilaian dari ahli materi, media dan siswa yang menghasilkan data sebagai berikut: (1) Oleh ahli materi memperoleh rata-rata 4,1 dalam kategori sangat baik. (2) Oleh ahli media memperoleh rata-rata 4,57 dalam kategori sangat baik. (3) Oleh siswa memperoleh rata-rata 3,2 dalam katego baik.
\end{abstract}

Kata kunci: evaluasi, bahan ajar bahasa Prancis, bahan ajar mandiri

\section{AN EVALUATION OF FRENCH LANGUAGE MATERIALS AS SELF-DIRECTED LEARNING MATERIALS FOR HIGH SCHOOL STUDENT}

\author{
Kartika Permata Sari \\ Prodi Teknologi Pembelajaran PPs UNY \\ saripermata.kartika@gmail.com
}

\begin{abstract}
The purpose of this study is to know the quality of French Le Mag teaching materials used by students as learning resources in the learning process. This study is an evaluation research using quantitative method approach. The evaluation model used in this research was a formative evaluation model by Dick and Carey which was conducted in two stages, one-to-one evaluation by expert and one to one evaluation by student. The results showed that learning material of French Le Mag was suitable to be used as self learning material of high school student. That results were based on the assessment of material experts, media expert and students which obtained the data: (1) By the material expert obtain an average of 4.10 in the criteria of very good. (2) By the media expert obtains an average of 4.57 in criteria very good. (3) By students earning an average of 3.2 in criteria good.
\end{abstract}

Keywords: Evaluation, French Learning Materials, Self-Directed Learning Materials 


\section{Pendahuluan}

Bahan ajar memiliki posisi yang sangat penting dalam pembelajaran, yaitu sebagai representasi (wakil) dari penjelasan guru di depan kelas. Di sisi lain, bahan ajar berkedudukan sebagai alat atau sarana untuk mencapai kompetensi inti. Bahan ajar juga berperan penting dalam memfasilitasi belajar baik di dalam proses pembelajaran maupun di luar proses pembelajaran. Bahan ajar termasuk bagian dari sumber belajar. Bahan ajar memegang peranan penting untuk membantu siswa mencapai tujuan pembelajaran. Sebagaimana yang dijelaskan oleh Depdiknas (Purmadi \& Surjono, 2016, p. 152) bahwa bahan ajar merupakan bagian penting dalam pelaksanaan pendidikan di sekolah. Melalui bahan ajar guru akan lebih mudah dalam melaksanakan pembelajaran dan siswa akan terbantu dan mudah dalam belajar.

Bahan ajar merupakan seperangkat materi yang disusun secara sistematis dan digunakan sebagai acuan dalam pembelajaran. Suparman (2014, p. 45) menyatakan bahwa bahan ajar disusun berdasarkan tujuan instruksional umum dan khusus, karakteristik peserta didik dan strategi instruksional. Tersedianya bahan ajar yang berkualitas akan mendukung keberhasilan proses pembelajaran. Bahan ajar bisa berpengaruh kuat dalam memberikan pengalaman belajar siswa. Bahan ajar sebagai salah satu sumber dan media dalam belajar turut menentukan tercapainya tujuan pembelajaran. Bahan ajar juga diartikan sebagai segala bentuk bahan yang digunakan untuk membantu guru atau instruktur dalam melaksanakan kegiatan pembelajaran di kelas.

Setiap siswa memiliki karakteristik belajar yang berbeda-beda, untuk memfasilitasi seluruh karakteristik belajar siswa tersebut dibutuhkan bahan ajar yang dapat membelajarkan siswa secara mandiri (Suparman, 2014, p. 312). Bahan ajar bersifat "mandiri", artinya dapat dipelajari oleh siswa secara mandiri karena sistematis dan lengkap (Pannen \& Purwanto, 2001, p.
7). Bahan ajar mandiri harus memenuhi kriteria sebagai bahan ajar mandiri yaitu self explanation dan self contents. Maksud dari self explanation adalah bahan ajar tersebut harus menggunakan bahasa yang jelas dan komunikatif agar siswa dapat memahami secara mandiri, karena pada dasarnya pembelajaran bahasa adalah pembelajaran yang komunikatif, seperti yang disampaikan oleh Sumiati bahwa Centre Européen Commun Références pour les Langues (CECRL) menyatakan pembelajaran bahasa Prancis dengan pendekatan komunikatif lebih menekankan pada perolehan kompetensi komunikatif (Sumiyati \& Surjono, 2014 , p. 200). Sedangkan self content adalah isi dari bahan ajar harus sangat lengkap.

Lebih lanjut dijelaskan bahwa bahan ajar yang dirancang dan dikembangkan berdasarkan prinsip-prinsip instruksional akan dapat membantu siswa dalam proses belajar dan membantu guru untuk mengurangi waktu penyajian materi karena siswa dapat belajar sendiri menggunakan bahan ajar (Pannen \& Purwanto, 2001, p. 6). Bahan ajar yang baik adalah bahan ajar yang disusun sesuai dengan tujuan instruksional dan sesuai dengan materi pembelajarannya. Bahan ajar yang disusun secara baik dapat memudahkan siswa dalam mempelajarinya sehingga siswa dapat mencapai kompetensi yang telah ditentukan. Baik dalam penelitian ini adalah sesuai dengan kriteria penyusunan bahan ajar. Kriteria-kriteria tersebut meliputi kriteria desain instruksional, kriteria desain pesan, kriteria strategi instruksional, dan kriteria karakteristik siswa

Pujiati (2007, p. 38) menjelaskan bahwa bahan ajar merupakan seperangkat materi/substansi pelajaran (teaching material) yang disusun secara sistematis, menampilkan sosok utuh dari kompetensi yang akan dikuasai siswa dalam kegiatan pembelajaran. Dengan bahan ajar memungkinkan siswa dapat mempelajari suatu kompetensi atau sub kompetensi secara runtut dan sistematis sehingga secara akumulatif mampu menguasai semua kompetensi secara utuh dan terpadu. 
Arti dari bahan ajar harus disusun secara sistematis adalah bahan ajar tersebut harus disusun secara sistematis dengan strategi penyajian uraian, contoh dan latihan atau contoh, latihan, penyajian uraian atau penyajian uraian, latihan dan contoh (Belawati, 2003, p. 25). Urutan strategi penyajian dapat saja berubah-ubah namun tetap harus diberikan penjelasan yang memadai agar siswa tidak bingung. Namun agar memudahkan siswa dalam belajar lebih baik jika urutan penyajiannya dilakukan secara konsisten.

Berdasarkan pendapat Pannen bahan ajar mandiri adalah bahan ajar yang sesuai dengan kriteria bahan ajar mandiri yaitu self explanation dan self content. Untuk menghasilkan bahan ajar yang self explanation dan self content tersebut, bahan ajar disusun berdasarkan prinsip-prinsip desain instruksional, desain pesan dan karakteristik siswa.

Dalam kaitannya dengan bahan ajar mandiri, perbedaan kemampuan belajar dan gaya belajar peserta didik dalam mempelajari bahasa Prancis menjadi faktor bahan ajar tersebut harus dapat dipelajari secara mandiri tanpa bimbingan guru. Jumlah peserta didik dalam satu kelas yang tidak ideal untuk pelajaran bahasa juga mempengaruhi. Sesuai dengan pasal 24 Permendikbud nomor 17 tahun 2017 untuk jenjang SMA jumlah siswa dalam satu kelas adalah minimal 20 dan maksimal 36 (luk.staff.ugm.ac.id.). Pada umumnya jumlah siswa dalam tiap kelas adalah 30 meskipun masih dalam hitungan jumlah siswa yang ideal, namun dengan jumlah siswa tersebut masih banyak siswa yang tidak mendapatkan giliran untuk praktk di kelas. Hal tersebut dikarenakan jam pelajaran yang masih kurang sehingga tidak semua peserta didik dapat mempelajari secara baik dalam kelas dan harus mempelajarinya sendiri di luar jam tersebut.

Pembelajaran bahasa Prancis di SMA menggunakan bahan ajar cetak berupa buku Le Mag. Meskipun para narasumber mengatakan bahwa dalam pembelajarannya menggunakan Le Mag, namun para guru dalam proses pembelajaran menggunakan pula bahan ajar yang lain untuk mendukung kelengkapan materi pembelajaran. Buku Le Mag merupakan buku terbitan Prancis yang memang didesain untuk siswa pada tahap pemula. Pada saat ini kualitas dari bahan ajar bahasa Prancis yang digunakan oleh guru terutama Le Mag belum diketahui. Belum diketahui pula apakah bahan ajar tersebut dapat digunakan siswa secara mandiri tanpa harus dengan bimbingan guru. Kualitas bahan ajar tersebut belum diketahui karena memang belum ada penelitian khusus yang meneliti apakah bahan ajar bahasa Prancis tersebut sesuai untuk pembelajaran mandiri atau tidak.

Berdasarkan pengertian teknologi pembelajaran yaitu teori dan praktik tentang desain, pengembangan, pemanfaatan, pengelolaan dan evaluasi, dapat diketahui bahwa dalam sebuah pembelajaran harus terdapat sumber belajar yang dikembangkan dan didesain agar dapat membelajarkan siswa. Untuk mengetahui apakah bahan ajar tersebut dapat membelajarkan dan memfasilitasi belajar siswa perlu dilakukan evaluasi terhadap bahan ajar tersebut. Dengan adanya evaluasi bahan ajar akan diketahui kualitas bahan ajar tersebut dan kemudian akan diambil keputusan apakah akan tetap digunakan atau diganti dengan bahan ajar yang lebih dapat membelajarkan atau merevisi yang telah ada. Penggunaan bahan ajar Le Mag yang telah digunakan sejak tahun 2007 dalam mata pelajaran bahasa Prancis di sekolah juga perlu dievaluasi untuk mengetahui kualitas bahan tersebut, agar dapat diambil kesimpulan apakah bahan ajar tersebut dapat digunakan oleh siswa secara mandiri.

Seperti yang telah dijelaskan sebelumnya untuk menghasilkan bahan ajar yang self explanation dan self content, bahan ajar perlu disusun berdasarkan desain instruksional, desain pesan dan karakteristik siswa. Menurut Reigeluth (1999, p. 5) instructional design theories are design oriented, they describe method of instruction and the situations in which those methods should be 
used. Menurut Reigeluth desain instruksional berorientasi pada desain, menjelaskan metode pengajaran dan situasi di mana metode tersebut harus digunakan. Komponen-komponen tersebut adalah tujuan instruksional, uraian materi, metode atau strategi, alat evaluasi,waktu pembelajaran, media dan alat pembelajaran. Pada penelitian evaluasi ini, peneliti hanya menggunakan komponen tujuan instruksional, strategi pembelajaran dan alat evaluasi.

Prinsip desain pesan digunakan agar pesan dari pembelajaran yang dituangkan ke dalam tulisan di bahan ajar dapat diterima dengan baik oleh siswa. Pesan yang terkandung dalam bahan ajar dapat dipahami dengan baik meskipun dengan cara mandiri.

Menyampaikan pembelajaran sesuai dengan konsep teknologi pendidikan dan pembelajaran pada hakikatnya merupakan kegiatan menyampaikan pesan kepada siswa oleh narasumber dengan menggunakan bahan, alat, teknik dan dalam lingkungan tertentu. Agar penyampaian materi tersebut efektif, perlu diperhatikan beberapa prinsip desain pembelajaran (Budiningsih, 2003, p. 118). Prinsip yang dimaksud adalah kesiapan dan motivasi, alat pemusat perhatian, partisipasi aktif siswa, umpan balik dan pengulangan. Selain kelima prinsip tersebut, dalam penelitian ini juga menggunakan prinsip desain pesan secara fisik. Desain pesan secara fisik meliputi penggunaan warna, huruf, tata letak dan penggunaan kertas serta kemenarikan gambar yang digunakan. Kriteria desain pesan secara fisik dinilai oleh ahli media.

Kriteria karakterakteristik siswa yang digunakan dalam penelitian ini adalah tingkat kesulitan materi sesuai dengan perkembangan kognitif siswa, tingkat kesulitan soal atau tes sesuai dengan karakteristik peserta didik, penggunaan bahasa sesuai dengan karakteristik peserta didik, penggunaan gambar sebagai pendukung teks sesuai dengan karakteristik peserta didik, penggunaan teks dalam segi keterbacaan sesuai dengan karakteristik peserta didik.
Evaluasi yang digunakan dalam penelitian ini adalah evaluasi formatif. Evaluasi formatif adalah salah satu sub domain dalam definisi teknologi pembelajaran. Seels (Oktarini \& Gafur, 2014, p. 41) menyebutkan bahwa evaluasi formatif adalah proses mengumpulkan informasi yang cukup dan menggunakan informasi ini sebagai basis bagi pengembagan lebih lanjutan dari objek yang dievaluasi.

\section{Metode}

Jenis penelitian ini merupakan penelitian evaluasi dengan pendekatan kuantitatif. Pendekatan evaluasi ini dirancang dengan menggunakan model The systematic design of Instruction by Dick \& Carey, namun akan dibatasi pada langkah ke delapan saja yaitu evaluasi formatif. Model evaluasi formatif Dick \& Carey terdiri dari tahap (1) evaluasi satu-satu oleh ahli, (2) evaluasi satu-satu oleh siswa, (3) evaluasi kelompok kecil, (4) uji coba lapangan (Suparman, 2014, p. 334). Namun pada penelitian ini akan dibatasi hanya sampai tahap kedua yaitu evaluasi satu-satu oleh ahli dan evaluasi satu-satu oleh siswa, untuk tahap ketiga dan keempat dapat dilakukan peneliti yang lain dalam penelitian pengembangan.

Evaluasi satu-satu oleh ahli dilakukan oleh ahli materi dan ahli media. ahli materi merupakan dosen bahasa Prancis dan peneliti. Ahli media adalah para teknolog pembelajaran yang ahli dalam bahan ajar cetak. Evaluasi satu-satu oleh siswa, dilakukan oleh 12 siswa dari 2 SMA. Pemilihan siswa berdasarkan rekomendasi guru pengampu mata pelajaran bahasa Prancis. 12 siswa tersebut terdiri dari 3 kelompok yaitu kelompok siswa pandai, siwa cukup dan siswa kurang.

Penelitian ini akan dilakukan di SMA Kota Yogyakarta yang mengajarkan bahasa Prancis. Di Kota Yogyakarta sendiri terdapat 4 SMA Kota Yogyakarta yang menerapkan bahasa Prancis sebagai mata pelajaran, namun hanya 2 SMA Kota yang menggunakan Le Mag dalam proses pem- 
belajaranyaa, yaitu SMA 6 dan SMA 10. Waktu penelitian dilaksanakan pada bulan Maret 2017.

Teknik pengumpulan data yang digunakan dalam penelitian ini adalah penyebaran kuesioner. Instrumen yang digunakan adalah angket. Angket dibuat berdasarkan teori yang digunakan dalam mengevaluasi bahan ajar. Angket dibagikan dan diisi oleh ahli untuk menilai kualitas bahan ajar. instrumen evaluasi dibedakan menjadi 3 jenis, instrumen untuk ahli materi, instrument ahli media dan instrumen untuk siswa. Instrumen ahli materi berisi kriteria bahan ajar berdasarkan desain instruksional, desain pesan dan karakteristik siswa. Sedangkan instrumen ahli media berdasarkan kriteria desain pesan secara fisik. Instruen untuk siswa berisi keterbacaan tek, kemenarikan isi materi, kemarinakn gambar dan kemudahan pemahaman bahasa. Validasi instrumen dilakukan dengan cara expert judgement atau penilaian ahli.

Teknik analisis data yang digunakan dalam penelitian ini adalah kantitatif deskripstif dengan kategori penilaian seperti pada Tabel 1.

Tabel 1. Tabel Kategori Penilaian Bahan

\begin{tabular}{ccl} 
& \multicolumn{2}{c}{ Ajar } \\
\hline No & Nilai & \multicolumn{1}{c}{ Kategori } \\
\hline 1 & $X>4,0$ & Sangat Baik \\
2 & $3,34<X \leq 4,0$ & Baik \\
3 & $2,26<X \leq 3,34$ & Cukup \\
4 & $1,99<X \leq 2,26$ & Kurang \\
5 & $X \leq 1,99$ & Sangat Kurang \\
\hline
\end{tabular}

\section{Hasil dan Pembahasan}

Seperti yang telah dijelaskan pada bab sebelumnya, bahwa penelitian ini adalah penelitian evaluasi. Penelitian ini tidak untuk menguji hipotesis dan tidak untuk menguji hubungan antar variable penelitian. Pada penelitian evaluasi ini ditujukan untuk memberikan informasi maupun mendeskripsikan temuan yang mendalam berdasarkan fakta dilapangan, apakah bahan ajar bahasa Prancis Le Mag sudah sesuai dengan kriteria sebagai bahan ajar mandiri untuk siswa SMA atau belum.

Data yang dikumpulkan dalam penelitian ini merupakan data kuantitatif. Data diperoleh dari para evaluator, evaluator tersebut terdiri dari 3 ahli materi, 3 ahli media dan siswa sebagai pelengkap. Ahli materi terdiri dari Dosen bahasa Prancis, Guru sekaligus penulis buku bahasa Prancis dan peneliti, dan ahli media terdiri dari 2 Dosen Teknologi Pendidikan dan Alumni mahasiswa pascasarjana Teknologi Pembelajaran.

Data yang diperoleh berupa angka yang kemudian dianalisis secara deskriptif kemudian diambil keputusan apakah bahan ajar bahasa Prancis Le Mag memiliki kualitas yang baik jika digunakan sebagai bahan ajar mandiri oleh siswa.

Penelitian Evaluasi Bahan Pembelajaran Bahasa Prancis sebagai Bahan Pembelajaran Mandiri Siswa SMA menghasilkan data yang berasal dari analisis konten dengan para evaluator. Para evaluator pada penelitian ini adalah ahli dalam bidang pembelajaran bahasa Prancis dan ahli dalam bidang bahan ajar cetak

Data yang diperoleh dari analisis konten dengan menggunakan teknik kuesioner para evaluator adalah data mengenai kualitas bahan pembelajaran dari aspek desain pembelajaran, desain pesan, dan karakteristik siswa. Data yang dihasilkan berupa skor penilaian ketiga aspek tersebut. Skor yang dihasilkan dikonfirmasikan pada kriteria evaluasi yang telah disusun pada bagian metode penelitian. Penskoran yang dilakukan para evaluator menghasilkan data kuantitatif terkait kualitas bahan pembelajaran bahasa Prancis.

Berdasarkan hasil evaluasi diperoleh 3 data dari ahli materi, ahli media dan siswa. Data dari ahli materi berdasarkan kriteria desain instruksional diperoleh ratarata 4,29 dalam kategori sangat baik. Kriteria desain instruksional terdiri dari 3 aspek yaitu tujuan pembelajaran, strategi pembelajaran dan alat evaluasi. Tujuan pembelajaran dalam bahan ajar ini sudah memenuhi komponen penyusun bahan 
ajar yang baik. Menurut Suparman (2014) komponen penyusun bahan ajar yang baik adalah ABCD (Audience, Behavior, Condition, Degree). Tujuan pembelajaran dalam bahan ajar Le Mag adalah Le Mag'1 a pour objectif de developer chez eleves leur competence a communiquer dans des situations elementaires de la vie quotidienne tout en leur faisant decouvrir different aspects de la culture francaise et francophone. Dalam bahasa dapat diartikan bahwa Tujuan Mag 1 adalah untuk mengembangkan kemampuan siswa dalam berkomunikasi dalam situasi dasar kehidupan sehari-hari sambil membuat mereka menemukan aspek budaya Prancis dan Francophone yang berbeda.

A: chez eleves ditujukan untuk siswa. Dalam bahan pembelajaran bahasa Prancis Le Mag halaman 3 disebutkan bahwa bahan pembelajaran ini ditujukan untuk pemula dalam mempelajari bahasa Prancis (Le Mag 1 s'adresse a un public de jeune adolescent debutant leur apprentissage de la langue francaise). Dalam bahan ajar bahasa Prancis khususnya bahan ajar yang diterbitkan langsung oleh para Native, subjek atau pengguna bahan ajar disebutkan dengan menyebutkan level kemampuan bahasa Prancisnya seperti A1 atau debutant tidak menyebutkan secara spesifik subjek atau pengguna bahan ajar tersebut.

B: developer chez eleves leur competence a communiqué dans des situations elementaires de la vie quotidienne. Komponen behavior dalam perumusan tujuan pembelajaran merupakan suatu tindakan atau perilaku yang diharapkan untuk siswa. Dalam bahan pembelajaran ini telah disebutkan bahwa behavior tujuan pembelajaran bahasa Prancis adalah meningkatkan kemampuan siswa dalam berkomunikasi sehari-hari.

C : tout en leur faisant decouvrir different aspects de la culture francaise et francophone (dengan menemukan perbedaan antara budaya Prancis dan francophone). Komponen condition adalah kondisi atau keadaan apakah siswa diharuskan menggunakan atau tanpa alat. Dalam bahan pembelajaran bahasa Prancis Le Mag dise- butkan bahwa siswa dapat berkomunikasi sehari-hari sembari mengenal perbedaan aspek budaya negara Prancis dengan negara fracophone (negara bekas jajahan Prancis yang menggunakan bahasa Prancis)

D: Il couvre environs 70 heured' enseignement. Dalam bahan pembeajaran ini disebutkan pula bahwa kurun waktu yang digunakan adalah 70 jam pelajaran bagi peserta didik untuk mencapai tujuan pembelajaran. Namun pada kurikulum bahasa Prancis SMA di Indonesia, bahan pembelajaran Le Mag digunakan selama 3 tahun atau dari kelas 1 sampai kelas 3 SMA.

Jadi sesuai dengan komponen perumusan tujuan pembelajaran menurut Suparman, bahan pembelajaran bahasa Prancis ini sudah memenuhi kriteria perumusan bahan pembelajaran yang baik karena sudah memuat komponen perumusan tujuan pembelajaran.

Pada aspek strategi pembelajaran memperoleh rata-rata 4,27 dalam kategori sangat baik. Dinyatakan sangat baik karena bahan ajar Le Mag telah disusun secara lengkap dan berurutan sesuai dengan komponen-komponen bahan ajar. Uraian materi dalam sebuah bahan pembelajaran harus sesuai dengan tujuan pembelajaran dan kurikulum yang digunakan. Dalam kurikulum tercantum standar kompetensi dan kompetensi dasar sebagai acuan dalam proses pembelajaran. Dalam kurikulum KTSP tujuan dari pembelajaran bahasa Prancis adalah agar para siswa memiliki kemampuan dasar dalam keterampilan mendengarkan, berbicara, membaca dan menulis untuk berkomunikasi secara sederhana (Departemen Pendidikan Nasional, 2003, p. 785).

Tujuan pembelajaran dalam Le Mag adalah Le Mag'1 a pour objectif de developer chez eleves leur competence a communiquer dans des situations elementaires de la vie quotidienne. Dalam bahasa dapat diartikan bahwa bahan pembelajaran ini ditujukan untuk siswa dalam meningkatkan kemampuan berkomunikasi dalam kehidupan sehari-hari. Kemampuan berkomunikasi 
dan berbahasa meliputi kemampuan berbicara, mendengarkan, menulis dan membaca. Menguasai komunikasi sehari-hari merupakan kemampuan dasar yang harus dikuasai oleh siswa.

Dalam peta materi pembelajaran bahasa Prancis untuk siswa SMA dari kelas x sampai dengan kelas xii tema pelajarannya meliputi perkenalan diri, kehidupan sekolah, kehidupan keluarga, kehidupan sehari-hari, kegemaran atau hobi dan wisata. Tema pelajaran tersebut sesuai dengan isi tema dalam bahan pembelajaran Le Mag, mulai dari unité 0 sampai dengan unité 8. Berikut ini tabel tema materi pelajaran dari peta pembelajaran bahasa Prancis dan tema materi pelajaran dalam buku Le Mag

Tabel 2. Peta Materi Pembelajaran Bahasa Prancis

\begin{tabular}{lll}
\hline $\begin{array}{l}\text { No Tema Materi } \\
\text { Pembelajaran Bahasa } \\
\text { Prancis }\end{array}$ & \multicolumn{1}{c}{$\begin{array}{c}\text { Tema Materi Buku Le } \\
\text { Mag }\end{array}$} \\
\hline 1 Identitas diri & $\begin{array}{l}\text { Unité 0 (premiers jours) - } \\
\text { Unité 1 (Je suis fan de) }\end{array}$ \\
2 Kehidupan sekolah & $\begin{array}{l}\text { Unité 2 (special college) - } \\
\text { unité 3 (tous different) }\end{array}$ \\
3 Kehidupan keluarga & $\begin{array}{l}\text { Unité 4 (la famille) - } \\
\text { unité } 7 \text { (la maison) }\end{array}$ \\
$4 \begin{array}{l}\text { Kehidupan sehari- } \\
\text { hari }\end{array}$ & Unité 6 (quelle journee) \\
5 Kegemaran atau & Unité 5 (vive le vacances) \\
6 hobi & Wisata & Unité 8 (on va faire la fete) \\
\hline
\end{tabular}

Berdasarkan Tabel di 2 dapat dilihat bahwa tema materi pembelajaran bahasa Prancis yang ditetapkan sesuai dengan tema materi yang terdapat pada buku Le Mag namun terdapat perbedaan dalam urutan penyampaiannya. Jika ditinjau berdasarkan kesesuaian isi materi dengan tujuan pembelajaran, bahan pembelajaran ini sudah sesuai, namun jika ditinjau berdasarkan kesesuaian urutan materi bahan pembelajaran ini tidak sesuai dengan silabus yang sudah dibuat, oleh karena itu siswa masih membutuhkan bimbingan dari guru. Tabel materi pembelajaran bahasa Prancis pada buku Le Mag dapat dilihat pada buku tersebut halaman empat sampai lima (tableau de contenu).

Tidak setiap materi terdapat contoh, namun dalam bahan pembelajaran ini masih memberikan contoh pada beberapa halaman dan beberapa materi yang perlu diberikan contoh agar siswa mampu memahami materi dengan baik. Contoh, adalah benda atau kegiatan yang terdapat dalam kegiatan siswa sebagai wujud dari materi pengajaran yang sedang diuraikan.

Rangkuman, merupakan uraian singkat dari materi yang telah dipelajari. Dalam bahan pembelajaran ini pada setiap akhir pembahasan materi (unite) terdapat rangkuman daftar kosakata yang digunakan dalam materi tersebut, untuk rangkuman dari keselurahan materi terdapat pada bagian Les actes de parole dan Precis grammatical.

Glosarium, daftar istilah teknis dan pengertian dari teori yang telah digunakan pada tahap penyajian. Dengan adanya glosarium siswa dapat dengan mudah memahami arti kata dan juga dapat memperbanyak perbendaharaan kata. Tidak terdapat glosarium atau daftar istilah dalam bahan pembelajaran ini, karena, bahan ajar ini merupakan bahan ajar terbitan Prancis.

Berdasarkan hasil penilaian secara kuantitatif komponen penutup memperoleh rata-rata 4,04 dalam kategori sangat baik. Komponen penutup meliputi latihan soal dan tes formatif. Tes formatif, merupakan suatu pertanyaan untuk dijawab atau seperangkat tugas untuk dilakukan untuk mengukur kemajuan belajar siswa setelah menyelesaikan suatu tahap pelajaran. tes ini dapat diajukan secara tertulis dan lisan. Petunjuk pengerjaan untuk bagian atelier langue dan fais le point telah dijelaskan pada bagian avant propos bahwa atelier langue merupakan latihan soal untuk tata bahasa sedangkan fais le point adalah latihan soal yang sesuai dengan standard delf A1. Ditinjau dari kesesuaian dengan tujuan pembelajaran, latihan soal sudah disusun agar siswa mampu berkomunikasi sehari-hari menggunakan bahasa Prancis. Proporsi soal dibagi berdasarkan kemampuan ber- 
bahasa yaitu membaca, menulis, mendengarkan dan berbicara, tidak hanya 4 kemampuan berbahasa saja latihan soal dalam bahan pembelajaran ini juga mengujikan kemampuan tata bahasanya.

Aspek Alat evaluasi memperoleh rata-rata 4,4 dalam kategori sangat baik. Ditinjau dari kesesuaian instrumen penilaian dengan tujuan pembelajaran, dalam bahan pembelajaran ini sudah tercantumkan dengan jelas. Disebutkan dalam bahan pembelajaran Le Mag halaman 3 (avant propos) "Pour chaque unite, une page "fais le point" structure par competences sur le modele du Nouveau DELF dans le livre élève" (untuk tiap unit, bagian "fait le point" disusun sesuai dengan model evaluasi DELF. Delf adalah ujicoba kemampuan bahasa Prancis yang diselenggarakan oleh centre international d'etudes pedagogiques dibawah wewenang kementrian pendidikan Prancis. Level A1 sesuai dengan level siswa SMA yang baru belajar bahasa Prancis (debutant). Level A1 menguji tentang kemampuan berbahasa Prancis siswa dalam berkehidupan sehari-hari. Keterampilan yang diujikan dalam DELF meliputi keterampilan membaca, menulis, mendengarkan dan berbicara. Hal ini sesuai dengan tujuan pembelajaran bahasa Prancis yang menuntut siswa untuk terampil dalam berkomunikasi sehari-hari yang meliputi keterampilan berbicara, mendengarkan, menulis dan membaca.

Pada kriteria desain pesan terdapat enam aspek, yaitu kesiapan dan motivasi, alat pemusat perhatian, partisipasi aktif siswa, umpan balik, pengulangan dan aspek desain pesan secara fisik. Tiap aspek terdiri atas beberapa sub-aspek. Aspek kesiapan dan motivasi terdiri dari dua subaspek yaitu kemampuan isi materi dalam memotivasi siswa dan penjelesan tujuan pembelajaran, dari kedua sub-aspek tersebut diperoleh rata-rata 3,83 termasuk dalam kriteria Baik. Sub-aspek kemampuan isi materi dalam memotivasi siswa menghasilkan rata-rata 3,67 dalam kriteria baik dan sub-aspek penjelasan tujuan pembelajaran menghasilkan rata-rata 4 dalam kriteria baik. Dalam mempelajari suatu materi yang benar-benar baru bagi siswa, menumbuhkan motivasi untuk mulai mempelajarinya merupakan langkah awal. Kemampuan isi materi dalam memotivasi siswa haruslah baik. Baik dalam artian materi tersebut dapat menimbulkan keinginan siswa untuk terus mempelajarinya. Pada bagian civilization dalam bahan pembelajaran ini menyajikan materi mengenalkan Prancis kepada siswa, baik itu budayanya, sejarah Prancis maupun tempat wisata yang terdapat di Prancis.

Unite 2 halaman 26 dan 27 menyajikan game/permainan sambil belajar mengenal Prancis dengan tema Voici $\mathrm{La}$ France. Pada bagian tersebut penulis menyajikan bagian-bagian yang kebanyakan orang kenal tentang Prancis seperti icon kota Paris yaitu menara Eiffel, symbol Prancis yaitu Marianne, makanan yang terkenal di Prancis yaitu Les Croissants dan Le Fromage. Unite 4 halaman 44 dan 45 menyajikan sejarah Prancis dan tokoh-tokoh terkenal dalam sejarah Prancis seperti Marie Antoinnet, Charles de gaule, Louis $\mathrm{XIV}$, Jeanne d'arc. Unite 6 halaman 62 dan 63 menyajikan tempat-tempat wisata yang ada di Prancis dan unite 8 halaman 80 membahas tentang hari-hari perayaan yang terjadi di Prancis.

Banyak cara untuk memberikan motivasi, antara lain dengan memberikan pujian, memberikan harapan, menjelas tujuan dan manfaat, memberi contoh, ataupun menceritakan sesuatu yang membuat siswa senang belajar, dengan mempelajari berbagai hal tentang Prancis dapat membuat siswa lebih termotivasi untuk mempelajari bahasa Prancis.

Prinsip pemusat perhatian menyatakan bahwa jika dalam penyampaian pesan digunakan alat pemusat perhatian, hasil belajar akan meningkat. Hal ini didasarkan atas pemikiran bahwa perhatian yaitu terpusatnya mental terhadap suatu objek yang memegang peranan penting terhadap keberhasialan belajar. Semakin memperhatikan semakin berhasil, semakin tidak memperhatikan semakin gagal.alat pemusat perhatian dapat berupa gambar, 
warna, layout, tulisan maupun lagu. Aspek alat pemusat perhatian terdiri dari 8 subaspek yaitu tampilan gambar pendukung, kemudahan istilah, kejelasan istilah, penggunaan bahasa, penggunaan gambar penjelas, kemenarikan gambar, keterkaitan dengan kehidupan sehari-hari dan keterkaitan materi dengan dengan materi sebelumnya. Berdasarkan kedelapan sub-aspek tersebut menghasilkan rata-rata 4,20 dalam kriteria sangat baik. Bentuk pemusat perhatian pada bahan pembelajaran ini adalah dengan penggunaan ilustrasi atau gambar pendukung dalam setiap teksnya. Penggunaan ilustrasi dapat mempermudah siswa dalam memahami bacaan. Dalam bahan pembelajaran ini ilustrasi diperjelas juga dengan pemberian nomor urutan pada setiap gambarnya, hal tersebut dapat semakin mempermudah siswa dalam memahami bacaan. Selain dengan ilustrasi, bentuk pemusat perhatian dalam bahan ajar ini adalah dengan lagu. Beberapa unite mencantumkan lirik lagu untuk dinyanyikan bersama-sama dalam proses pembelajarannya. Lagu tersebut tidak hanya sekedar lagu penggembira saja namun bagian dari materi juga. Pengunaan lagu juga mampu mempermudah siswa untuk mengingat materi.

Aspek partisipasi aktif siswa terdiri dari dua sub-aspek yaitu pemberian latihan dalam setiap bahasan dan ketepatan pemberian latihan yang membuat siswa bekerja secara kelompok. Dua sub-aspek tersebut menghasilkan rata-rata 5 dalam kriteria sangat baik. Aspek umpan balik terdiri dari tiga aspek yaitu kejelasan pembahasan soal, pemberian nilai/skor setiap latihan soal, dan kemampuan umpan balik dalam memotivasi belajar siswa. Ketiga sub-aspek tersebut menghasilkan rata-rata 3,14 termasuk dalam kriteria cukup. Aspek pengulangan terdiri dari dua sub-aspek yaitu penggunaan kalimat perulangan dan kejelasan kesimpulan setelah materi, dari kedua sub-aspek tersebut mebghasilkan rata-rata 3,67 termasuk dalam kriteria baik. Bahan pembelajaran ini lebih mengutamakan latihan-latihan dan tugas-tugas untuk siswa dibandingkan dengan uraian materi. Hal ini dimaksudkan agar siswa lebih sering mempraktikkan bahasa yang sedang dipelajari. Bentuk partisipasi aktif siswa dalam bahan pembelajaran ini tidak hanya dengan tugas individu namun juga dalam bentuk tugas kelompok. Pada bagian $\grave{A}$ toi! lebih sering meminta siswa untuk bekerja secara kelompok.

Hasil data kuantitatif menyatakan bahwa rata-rata pada aspek umpan balik adalah 3,25 dalam kategori cukup. Jika dalam penyampaian pesan siswa diberi umpan balik, hasil belajar akan meningkat. Umpan balik adalah informasi yang diberikan kepada siswa mengenai kemajuan belajarnya. Jika salah diberikan pembetulan dan jika betul diberi konfirmasi atau penguatan. siswa akan menjadi mantap kalau betul kemudian dibetulkan. Sebaliknya, siswa akan tahu dimana letak kesalahan jika diberi tahu kesalahannya kemudian diberikan dalam bentuk kunci jawaban yang benar, namun pada bahan pembelajaran ini tidak terdapat pembahasan soal. Bahan pembelajaran mandiri didesain untuk siswa belajar secara mandiri tanpa bantuan pengajar, jika tidak terdapat pembahasan maka siswa tidak mengetahui apakah pekerjaan yang telah mereka kerjakan benar atau salah. Meski tidak terdapat pembahasan soal namun pada halaman 3 (avant propos) terdapat kriteria penilaian yang menjadi patokan dalam menilai soalsoal latihan. Setiap soal mendapat nilai maksimal 20, patokan tersebut sesuai dengan kriteria penilaian ujian DELF.

Berdasarkan hasil penilaian data kuantitatif aspek pengulangan memperoleh rata-rata 3,62 dalam kategori cukup. Jika penyampaian pesan pembelajaran diulang-ulang, maka hasil belajar akan lebih baik, perulangan dilakukan dengan mengulangi dengan cara yang berbeda-beda. Perulangan dapat pula dilakukan dengan memberikan tinjauan selintas awal pada saat memulai pelajaran dan ringkasan atau kesimpulan pada akhir pelajaran. Perulangan dalam bahan pembelajar dapat berupa rangkuman pada akhir pembahasan. 
Pengulangan dapat berupa pengulangan kalimat maupun pengulangan gambar. Bentuk pengulangan dalam bahan ajar ini berupa pengulangan materi. Materi yang telah dibahas pada unite sebelumnya, dibahas lagi pada unite berikutnya. Hal ini bertujuan agar siswa lebih menguasai materi tersebut. Selain itu rangkuman dalam setiap unite dan pada akhir unite merupakan bentuk pengulangan yang terdapat dalam bahan ajar Le Mag.

Pada kriteria karakteristik siswa terdiri dari beberapa aspek untuk menilai kesesuaian bahan pembelajaran dengan karakteristik siswa. Hasil penilaian dari sub-aspek tingkat kesulitan materi sesuai dengan perkembangan kognitif siswa memperoleh rata-rata 3,33 dalam kategori sesuai. Sub-aspek tingkat kesulitan soal sudah sesuai dengan karakteristik siswa dengan rata-rata 3,33. Ditinjau dari tingkat kesulitan materi, materi dalam bahan pembelajaran ini ditujukan atau memang disusun untuk pemula (debutant). Meskipun ditujukan untuk pemula namun bahan pembelajaran ini tidak terlalu banyak menyampaikan teori. Siswa pada usia 15-17 tahun dinilai mampu untuk berpikir abstrak dan logis dengan menggunakan pola pikir oleh karena itu bahan pembelajaran ini lebih mengutamakan kemampuan siswa dalam menarik kesimpulan dan kreativitas berpikirnya. Tingkat kesulitan soal pun sudah sesuai dengan standart delf A1 (debutant).

Sub-aspek penggunaan bahasa sudah sesuai dengan karakteristik siswa, hal ini dibuktikan dengan perolehan rata-rata 4 pada kategori sesuai. Dalam segi keterbacaan tekspun dinilai sangat baik dan sesuai dengan karakteristik siswa, dengan ratarata 4,67 dalam kategori sesuai. Sub-aspek kesesuaian penggunaan gambar sudah sesuai dengan karakteristik siswa dengan memperoleh rata-rata 4 dalam kategori sangat sesuai. Penggunaan teks dalam segi keterbacaan sesuai dengan tingkat karakteristik siswa. Ukuran teks yang baik digunakan untuk siswa SMA adalah 12 . Ukuran tersebut tidak terlalu kecil dan tidak terlalu besar. Penggunaan huruf besar hanya untuk judul

Tabel 3 merupakan hasil evaluasi dari kriteria desain instruksional, desain pesan dan karakteristik siswa oleh ahli materi.

Tabel 3. Hasil Penilaiana Ahli Materi

\begin{tabular}{llcl}
\hline No & Kriteria & $\begin{array}{c}\text { Rata- } \\
\text { rata }\end{array}$ & Kategori \\
\hline 1. & Desain Instruksional & 4,29 & Sangat Baik \\
2. & Desain Pesan & 4,01 & Sangat Baik \\
3. & Karakteritik Siswa & 4,00 & Sangat Baik \\
\hline
\end{tabular}

Berdasarkan data kuantitatif, aspek desain pesan secara fisik memperoleh ratarata 4,5 dalam kriteria sangat baik. Aspek desain pesan secara fisik meliputi konsistensi proporsi layout, penggunaan variasi bentuk huruf, keterbacaan teks segi ukuran huruf dan proporsi penggunaan warna latar belakang dan warna teks. Menurut Atwi Suparaman dalam bahan pembelajaran mandiri desain fisik merupakan daya tarik yang penting diperhatikan.

Khusus untuk bahan pembelajaran cetak, harus artistic, rapi, menarik dan diketik dengan jelas (tidak terlalu rapat). Bentuk fisik ini penting diperhatikan karena bahan pembelajaran mandiri yang tampak buruk akan mengurangi keinginan siswa untuk mempelajarinya walaupun isinya sudah cukup baik. Pengguna pada umumnya memperhatikan penampilan fisiknya, mereka melihat bentuk, warna dan cara penataan dalam menyajikannya terlebih dahulu, sedangkan isinya dinilai kemudian.

Sampul bahan pembelajaran menggunakan gambar remaja seusia pelajar SMA dan menggunakan tulisan yang berwarna-warni untuk menarik perhatian siswa. Pada halaman berikutnya tertera level atau tingkatan bahan pembelajaran ini dan pengarang beserta percetakannya. Tidak ada yang ditonjolkan paa halaman ini, latar belakang hanya menggunakan warna putih dan judul berukuran lebih besar dari 
tulisan lainnya dengan warna merah muda dikombinasikan warna kuning.

Pada setiap bab dalam bahan pembelajaran ini memiliki warna latar belakang yang berbeda-beda. Kotak teks menggunakan warna yang lebih terang dibandingkan latarb elakang keseluruhan halaman. Berdasarkan hasil penilaian bahan pembelajaran ini menggunakan warna latar belakang yang tidak terlalu mencolok sehingga teks atau bagian-bagian penting lainnya terlihat lebih menonjol. Bahan pembelajaran ini menggunakan warna-warna dasar yang memberikan efek baik bagi penggunanya. Tabel 4 merupakan hasil penilaian bahan ajar oleh ahli media

Tabel 4. Hasil Penilaian Ahli Media

\begin{tabular}{llcl}
\hline No & $\begin{array}{c}\text { Kriteria Desain Pesan } \\
\text { Oleh Ahli Media }\end{array}$ & $\begin{array}{c}\text { Rata- } \\
\text { rata }\end{array}$ & Kategori \\
\hline 1. & Warna & 4,5 & Sangat Baik \\
2. & Huruf (font) & 4,25 & Sangat Baik \\
3. & Tata Letak (Layout) & 4,33 & Sangat Baik \\
4. & Gambar & 4,77 & Sangat Baik \\
5. & Penggunaan Kertas & 4,83 & Sangat Baik \\
\hline
\end{tabular}

Selain melalui evaluasi oleh para ahli materi dan media, bahan ajar ini juga dievaluasi oleh siswa untuk mengetahui kemenarikan dan kemudahan bahan pembelajaran ini untuk digunakan sebagai bahan pembelajaran mandiri siswa. Siswa yang menjadi evaluator adalah siswa yang cenderung belajar secara mandiri. Dari dua sekolah menengah atas di kota Yogyakarta yang memasukkan bahasa Prancis sebagai mata pelajaran diambil enam siswa tiap sekolah. Enam siswa tersebut terdiri dari dua siswa yang pandai, dua siswa yang cukup dan dua siswa yang kurang. Siswa dipilih berdasarkan rekomendasi oleh guru pengampu mata pelajaran, hal ini dilakukan karena guru pengampu mengetahui tingkatan siswa dari yang pandai, cukup dan yang kurang. Hasil penilaian siswa menghasilkan rata-rata 3,2 dalam kriteria sangat baik. Tabel 5 merupakan hasil penilaian bahan ajar oleh pengguna atau siswa.
Tabel 5. Hasil Penilaian Pengguna (Siswa)

\begin{tabular}{llll}
\hline No & Aspek yang dinilai & $\begin{array}{l}\text { Rata- } \\
\text { rata }\end{array}$ & Kategori \\
\hline 1. & Keterbacaan Teks & 3.34 & Baik \\
2. & Kemenarikan Gambar & 3.26 & Baik \\
3. & Kemenarikan Isi Materi & 3.16 & Baik \\
4. & Kemudahan Pemahaman & 3.05 & Baik \\
& Kalimat & & \\
\hline
\end{tabular}

Berdasarkan penilaian dari siswa diperoleh rata-rata 3,2 dalam kategori sangat baik, hal tersebut menyatakan bahwa bahan ajar Le Mag dapat digunakan siswa dengan baik untuk pembelajaran mandiri. Dilihat dari hasil terbacaan teks, siswa menilai bahwa teks yang digunakan dalam bahan ajar dapat terbaca dengan jelas oleh siswa, hal ini dibuktikan dengan rata-rata hasil penilaian yaitu 3,34. Kriteria teks atau font yang ideal agar terbaca baik oleh siswa SMA adalah ukuran 12. Cetak tebal dan miring digunakan untuk penanda hal penting, misal huruf cetak tebal dan ukuran lebih besar biasanya digunakan untuk judul tema.

Pada aspek kemenarikan gambar rata-rata hasil penilaian siswa diperoleh 3,26 dalam kategori baik. Gambar yang disajikan dalam bahan ajar ini sangat beragam, dan tidak hanya beragam namun gambar dalam bahan ini merupakan ilustrasi dari teks yang disajikan. Jika bahan ajar hanya disajikan dalam teks saja, siswa debutant akan sulit dalam memahami teks, namun dengan bantuan gambar pendukung teks siswa dapat lebih mudah dalam memahami teks, seperti yang dinyatakan oleh Carney \& Levin (2002, p. 9) bahwa gambar dapat meningkatkan pemahaman siswa karena gambar dapat membuta sebuah teks menjadi lebih menarik untuk dibaca dan dapat memusatkan perhatian siswa.

Aspek kemenarikan isi materi memperoleh rata-rata 3,16 dalam kategori baik. Kemenarikan isi materi meliputi kemudahan siswa dalam mempelajari materi dan materi yang disajikan dapat menumbuhkan motivasi siswa dalam belajar bahasa Prancis. Syarat agar siswa mudah dalam mempelajari materi adalah dengan penyu- 
sunan materi yang runtut, dari materi yang mudah ke materi yang sulit. Selain itu komponen-komponen uraian materi seperti teks, contoh, rangkuman dan latihan soal disajikan secara lengkap dan berurutan. Latihan soal tidak hanya dilakukan secara individu tetapi juga berkelompok. Berdiskusi dengan teman sebaya dapat pula meningkatkan pemahaman siswa. Kemampuan materi dalam memotivasi siswa ditunjukkan dengan penggunaan contoh dengan mengilustrasikan kehidupan sehari-hari semakin membuat siswa mudah dalam memahami materi. Selain itu dengan menyajikan contoh-contoh kebudayaan Prancis yang dapat dipelajari siswa.

Pada aspek kemudah pemahaman kalimat memperoleh rata-rata 3,05 dalam kategori baik. Kalimat yang digunakan dalam bahan ajar ini dapat mudah dipahami oleh siswa karena menggunakan bahasa yang lugas dan komunikatif. Dalam bahasa Prancis kita mengenal kalimat formal dan informal atau tu toyes dan vous voyez, pada kalimat perintah biasanya ditulis dalam kalimat formal seperti observez! maksudnya adalah meminta siswa untuk menganalisis atau memaham. Namun dalam bahan ajar ini menggunakan pola kalimat $t u$ toyes atau informal, hal ini dapat membuat siswa seolah-olah berkomunikasi langsung dengan pengajarnya. Kosakata yang digunakan dalam kalimat pada bahan ajar ini disesuaikan dengan kemampuan siswa debutant sehinggan tanpa bantuan gurupun siswa dapat memahami kalimat dengan baik.

\section{Simpulan}

Berdasarkan hasil evaluasi yang dilakukan oleh ahli media dan ahli materi juga data dari siswa yan diambil di SMA 6, SMA 10 dan pembahasan yang telah diuraikan dalam bab IV, evaluasi bahan pembelajaran bahasa Prancis Le Mag karangan Celine Himber et al sebagai bahan pembelajaran mandiri berdasarkan kriteria desain instruksional, desain pesan, strategi pembelajaran, karakteristik peserta didik dan teori belajar yang digunakan di beberapa SMA di Kota Yogyakarta dapat disimpul- kan bahwa bahan pembelajaran bahasa Prancis Le Mag memenuhi kriteria sebagai bahan pembelajaran mandiri dan baik digunakan sebagai bahan pembelajaran mandiri siswa. Kesimpulan tersebut dibuktikan dengan hasil penilaian oleh ahli Materi yang menghasilkan data pada kriteria desain instruksional diperoleh rata-rata sebesar 4,29 dalam kategori sangat baik. Kriteria desain pesan secara keseluruhan memperoleh rata-rata 4,01 dalam kategori sangat baik dan. Bahan pembelajaran Le Mag sudah sesuai dengan karakteristik peserta didik, hal ini dibuktikan dengan perolehan rata-rata pada kriteria karakteristik peserta didik yaitu 4,00 dalam kategori sangat baik. Oleh ahli media berdasarkan kriteria desain pesan bahan pembelajaran Le Mag sudah memenuhi kiteria sangat baik dengan rata-rata 4,57 dalam kategori sangat baik. Oleh siswa menghasilkan rata-rata 3,2 dalam kriteria baik

\section{Daftar Pustaka}

Belawati, T. (2003). Pengembangan bahan ajar. Jakarta: Pusat Penerbitan Universitas Terbuka.

Budiningsih, C. A. (2003). Desain pesan pembelajaran. Yogyakarta: FIP UNY.

Carney, R. N., \& Levin, J. R. (2002). Pictorial illustrations still improve students' learning from text. Educational Psychology Review, 14(1), 526.

https://doi.org/10.1023/A:101317630 9260

Departemen Pendidikan Nasional. (2003). Kurikulum 2004 standar kompetensi mata pelajaran Bahasa Prancis. Jakarta: Depdiknas.

Oktarini, E., \& Gafur, A. (2014). Evaluasi formatif pada video pembelajaran Majoe Djaya produksi eduartion. Jurnal Inovasi Teknologi Pendidikan, 1(1). Retrieved from https://journal.uny.ac.id/index.php/ jitp/article/view/2458 
Pannen, P., \& Purwanto. (2001). Penulisan bahan ajar. Jakarta: Depdiknas.

Peraturan Menteri Pendidikan Dan Kebudayaan Republik Indonesia Nomor 17 Tahun 2017. Diakses pada 13 November 2017 https://luk.staff.ugm.ac.id/atur/bsn p/Permendikbud17-2017PPDB.pdf

Pujiati. (2007). Pengembangan bahan ajar praktikum pengantar akuntansi untuk mahasiswa Jurusan Akuntansi. Jurnal Ekonomi dan Pendidikan (Vol. 4). Retrieved from https://journal.uny.ac.id/index.php/ jep/article/view/609

Purmadi, A., \& Surjono, H. D. (2016). Pengembangan bahan ajar berbasis web berdasarkan gaya belajar siswa untuk mata pelajaran Fisika. Jurnal
Inovasi Teknologi Pendidikan, 3(2), 151. https:// doi.org/10.21831/jitp.v3i2.82 85

Reigeluth, C. M. (1999). Instructional-design theories and models volume II, a new paradigm of instructional theory. New Jersey: LEA.

Sumiyati, S., \& Surjono, H. D. (2014). Pengembangan multimedia pembelajaran untuk meningkatkan penguasaan kala lampau bahasa prancis mahasiswa. Jurnal Inovasi Teknologi Pendidikan, 1(2). Retrieved from http://journal.uny.ac.id/index.php/ji tp/article/view/2530

Suparman, A. (2014). Desain instruksional modern. Jakarta: Erlangga. 